\section{An analysis of news headlines under the light of Relevance Theory, newsworthiness and sensationalism}

\author{
Uma análise de manchetes \\ à luz da Teoria da \\ Relevância, noticiabilidade e \\ sensacionalismo
}

Ana Larissa Adorno Marciotto OLIVEIRA (UFMG) adornomarciotto@gmail.com

Gustavo Ximenes CUNHA (UFMG) ximenescunha@yahoo.com.br

Bruna Monteiro de SIQUEIRA (UFMG) bmonteirosiqueira@gmail.com

Recebido em: 15 de set. de 2020. Aceito em: 15 de jan. de 2021.

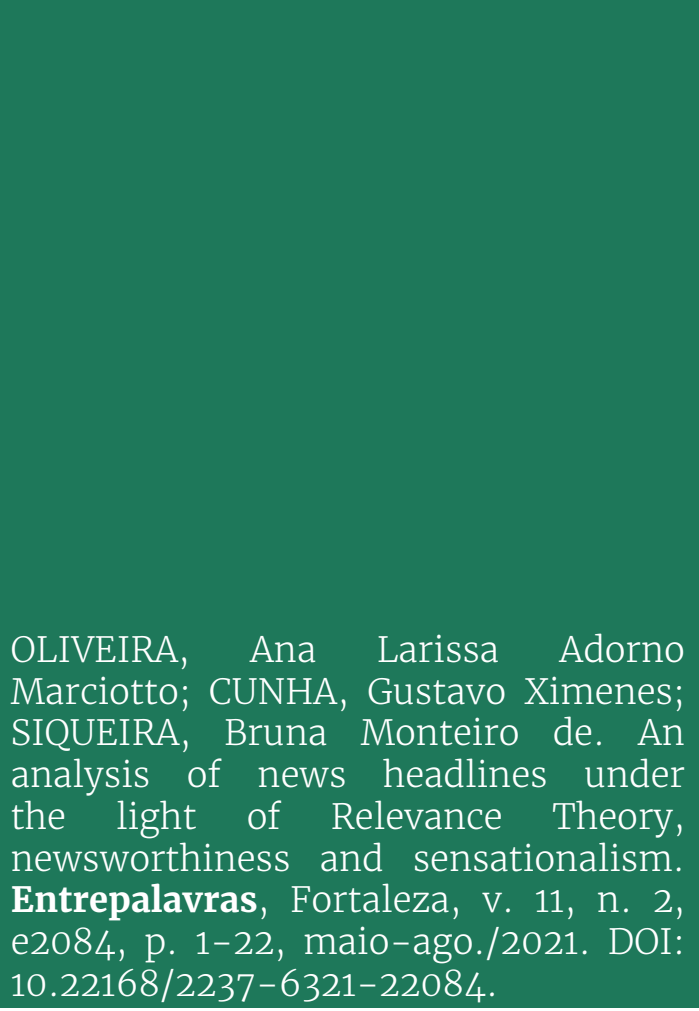

Abstract: From the perspective of the Relevance Theory, an utterance is considered "relevant" to the extent that its positive cognitive effects are large and the mental processing effort is small. Taken that news headlines may be designed to optimize relevance, as well as to promote newsworthiness and sensationalism, the central aim of this study is to analyze Brazilian news headlines in an attempt to associate some tenets of Relevance Theory to the notions of newsworthiness and sensationalism. In order to carry out the study, 56 front pages from major Brazilian newspapers, extracted from the Corpus de Manchetes Brasileiras (CMB Brazilian News headline Corpus), were analyzed. After the main headlines were identified, a sample was formed in order to carry out the qualitative analysis. The results showed how news headlines packed information in such a way that the news items many times appeared more significant and novel than it was the case. More particularly, the study also demonstrated how the headlines analyzed typically connected the concept of newsworthiness to the principles of Relevance Theory, while also working as click-baits to attract the reader to the news story.

Key words: News headlines. Relevance theory. Newsworthiness. 
V. $11(2)$

1-22

maio-ago

2021

Resumo: Na Teoria da Relevância, um enunciado é considerado mais "relevante" quanto maiores são seus efeitos cognitivos e menor o esforço mental requerido para seu processamento. Considerando que as manchetes podem ser elaboradas para otimizar a relevância, bem como para promover noticiabilidade (newsworthiness) e sensacionalismo, o objetivo central deste estudo é analisar manchetes brasileiras na tentativa de associar alguns princípios da Teoria da Relevância às noções de "noticiabilidade" e sensacionalismo. Para a realização do estudo, foram analisadas 56 capas de grandes jornais brasileiros, extraídas do Corpus de Manchetes Brasileiras (CMB - Brazilian News headline Corpus). Após a identificação das principais manchetes, criou-se uma amostra para a realização da análise qualitativa. Os resultados mostraram como as manchetes apresentam as informações de tal forma que as notícias muitas vezes parecem ser mais significativas e originais do que realmente são. Mais especificamente, o estudo demonstrou como as manchetes analisadas conectam tipicamente o conceito de noticiabilidade aos princípios da Teoria da Relevância, funcionando como "iscas" para atrair o leitor para a notícia.

Palavras-chave: Manchetes. Teoria da Relevância. Noticiabilidade.

\section{A bird's eye view of the research}

In light of Relevance Theory (WILSON; CARSTON, 2007), an important feature of a "relevant" input concerns its potential to trigger the formation of implicated conclusions drawn at a low processing cost. In this process, the information in the utterance, together with the real-world knowledge and the sensory input are employed to infer meanings. An utterance is thus considered "relevant" to the extent that its positive cognitive effects are large and the mental processing effort is small. Hence, the notion of "relevance" has a comparative property: "the more positive cognitive effects and the less processing effort, the more relevant the utterance will be" (CARSTON, 2002, p. 26).

The concept of relevance is involved in the construction of news headlines, once they are designed to optimize the relevance of the news reports accompanying them. Consequently, composing successful headlines requires knowledge about the reader's beliefs, expectations and cognitive style. For this reason, news outlets often prioritize "recent, intense and wide in scope and scale issues" (MONTGOMERY, 2007, p. 4). From this perspective, an audience-driven definition of news encompasses "information about current or recent events, happenings or changes taking place outside the immediate purview of the audience and which is considered to be of likely interest or concern to them" (MONTGOMERY, 2007, p. 4).

Similarly, issues that involve conflict or negativity, public figures, powerful nations or institutions are extensively covered in order to strengthen newsworthiness. In turn, news headlines ought to 
be attractive, concise and unexpected, so that they can call the reader's attention. With regards to textual composition, it is important that "the stories are not too long, too complicated or too time consuming" (MONTGOMERY, 2007, p. 15). Following that framework, the central aim of this study is to analyze a sample of news headlines, extracted from the website Newseum in the year 2018. The main purpose of this analysis was to investigate if/how the framework of Relevance Theory can be associated to the concepts of newsworthiness and/or sensationalism in the headlines on focus.

In the next section of this, we will outline the theoretical framework that underpins this research, particularly formed by Relevance Theory.

\section{Relevance Theory}

Departing from Grice's (1975) inferential model, Sperber and Wilson (1995) developed a theoretical framework based on the interpretation of utterances in context. For those authors, however, the notion of context encompasses physical, sensorial, and encyclopedic input stemming from the cognitive environment, and being potentially relevant to the interpretation of an utterance. More specifically, a major departure from Gricean's framework is that, for Relevance Theory, the explicit and implicit portions of communication are both inferential and worthy of the interlocutors' attention (SPERBER; WILSON, 1995). According to that approach, individuals only attend phenomena that seem relevant to them. Relevance Theory (RT) is thus based on the notion that speakers/ readers commonly draw their attention to stimuli that somehow meet their interests, or that can conform to the circumstances of the immediate context (SILVEIRA; FELTES, 1999). By aiming at revisiting Grice's Maxims, the Principle of Relevance, according to which "every act of ostensive communication carries a presupposition of its own optimal relevance" (SPERBER; WILSON 1995, p. 158), encompasses the notion that any ostensive stimulus from the speaker is potentially worthy the recipient's processing effort. From that perspective, communication occurs when the speaker produces a stimulus in order to manifest his informational intention. As a consequence, the speaker, in producing a stimulus-utterance, makes it explicit that a set of assumptions has become mutually manifest for both 
V. $11(2)$

$1-22$

maio-ago

2021

the speaker himself and the listener. Hence, in RT, an utterance is conceived of as a direct and ostensive evidence of the speaker's informational intention (SPERBER; WILSON 1995).

More particularly, RT views communication as ostensive from the speaker's part, while inferential from the listener's viewpoint. In this sense, once an utterance can catch the attention of the listener, it will typically lead to the construction and to the manipulation of certain mental representations. In the process, the stimulus-utterance on the listener's focus of attention typically conflates different information stored in his mind, potentially giving rise to manifold assumptions and inferences. In turn, from the perspective of RT, the assumptions and inferences resulting from the comprehension of an utterance are called "contextual effects".

According to Sperber and Wilson (1995), contextual effects are assumptions resulting from the interaction of new information (or of information recently introduced in short-term memory) with and the individual's cognitive environment, resulting in communicative effectiveness. Contextual effects also concern the assumptions whose novelty lies neither in information recently introduced nor in existing information. Combining both types of information, contextual effects represent interactional spin-offs that imply a change in the individual's beliefs (SILVEIRA; FELTES, 1999). In this view, the relevance of a stimulus highly depends on the amount of contextual effects that it allows for the individual to produce, leading to the modification of his representation of the world. Contextual effects can occur in three different ways: (i) via contextual implication, (ii) via strengthening or weakening the assumptions, and (iii) via eliminating contradictory assumptions.

i) An assumption arising from contextual implication results from a combination of existing information (or assumptions) with new information (or new assumptions). It results, therefore, from the assimilation of new assumptions in the context of already existing ones.

ii) The second type of contextual effect is the modification of an already existing assumption. In that case, there is no new assumption involved, but rather the strengthening or the weakening of an assumption that had been previously formed in the listener's/reader's mind. 
iii) The last type of contextual effect is the elimination of an assumption, when it contradicts another one. In that case, the assimilation of an assumption in a context that contradicts it may lead to the elimination of an already existing assumption. In sum, an assumption lacking appropriate evidence is typically eliminated. (SPERBER; WILSON, 1995).

Along these lines, it is also important to emphasize the role of context in the emergence of contextual effects. From the view point of $\mathrm{RT}$, the context used to process new information is seen as "a subset of old assumptions of the individual, with which new assumptions combine to produce a variety of contextual effects" (SPERBER; WILSON, 1995, p. 132). In the search for contextual effects that justify the processing of the new information, the individual selects, from the assumptions that make up his representation of the world, a subset of assumptions adequate for him to interpret the new information imparted. In that process, it is noteworthy to mention that the term 'context' means the individual's cognitive environment. The cognitive environment, in turn, is formed by the mentally represented assumptions about the world that affect communication.

Following that view, Sperber and Wilson (1995) point out that the choice of context, that is, the information that constitutes the cognitive environment of the individual, is not arbitrary. According to the authors, the organization of the encyclopaedic memory of the individuals, together with the mental activity in which they engaged in, limit the type of potential contexts from which the context can be selected at a given moment (SPERBER; WILSON, 1995, p. 138). That means that the selection of a context is guided by a search for contextual effects, that is, for relevance: in order to contextualize new information, one chooses information present in the memory that may lead to the production of a greater amount of contextual effects. Hence, it is the expectation that the information in process is relevant that causes individuals to pick a context that meets their expectations.

For this reason, a context that maximizes the relevance of an utterance, by allowing for the production of more contextual effects, is typically chosen. According to Sperber and Wilson (1995), information forming the context can stem from several different sources. They can come from a previous utterance or from a more distal source, 
V. 11 (2)

$1-22$

maio-ago

2021

ranging from the physical environment to the encyclopedic knowledge, for example. As once can see, the term "context" in this theoretical framework is not fixed. On the contrary, while the expectations of individuals concerning relevance are always constant, the context is seen as prone to change.

Another component of the search for relevance is the processing effort. All mental activities require some effort or expenditure of energy in terms of perception, memory, and inference. The effort required by mental activities consists of a comparative property in terms of the potential spins-offs, or the contextual effects to be achieved (WILSON; SPERBER, 2005).

In sum, the notion of relevance is not an absolute one. It is a comparative concept according to which the more contextual effects an utterance yields, the more relevant it will be (WILSON; SPERBER, 2005). Along with those lines, the more an utterance demands cognitive efforts, the less relevant it will be. As a consequence, by virtue of that notion, an utterance demanding less processing effort will be more relevant than another one involving a greater amount of effort.

Despite this comparative property of relevance, Silveira and Feltes (1999) point out the existence of certain communicative situations in which an additional effort may be rewarded with a greater amount of contextual effects. The authors compare this process with a situation in which one attempts to bend a metal bar. The bar can be easily bent up to a certain point; however, the complete bending of it will only be achieved after some additional effort is made. In that case, an optimal outcome may demand a greater expenditure of effort. The situation is exemplified by the authors with the following example (SILVEIRA; FELTES, 1999, p. 45-46):

\section{(1) A: A whiskey? \\ B: I'm a Mormon.}

The effort required to understand the B's indirect response is greater than the one potentially involving the understanding of a direct response, such as "Yes" or "No". At the same time, while providing an indirect and therefore more demanding response, B assumes that the information "Whiskey is an alcoholic beverage" and "Mormons do not drink alcoholic drinks" may be part of A's encyclopedic knowledge, and thus can prompt a broader interpretation of B's response. In this 
case, B's response will lead to the following assumption: "B does not drink alcohol" and "Alcohol should not be offered again". That said, Example 1 illustrates how a greater expenditure of cognitive efforts can sometimes compensate for the production of a greater amount of contextual effects.

Taking that news-headlines can be seen as relevance optimizers, the following section revisits some studies that associate RT with the concept of newsworthiness and sensationalism in the construction of headlines.

\section{News-headlines as relevance optimizers}

When discussing the concepts of news and newsworthiness, Shoemaker (2006) states that "newsworthiness is a mental construct, a thought or judgment, whereas news is a social artifact, a thing" (SHOEMAKER, 2006, p. 3). The decision on what will become news involves several different variables, newsworthiness being only one of them. That said, Shoemaker (2006) also underscores that newsworthiness should not be used as a "solely predictor of what will potentially become news": "We should no longer use the prominence with which events are covered as a measure of the event's newsworthiness, and our theories should not use newsworthiness as the sole (or even an important) predictor of what becomes news" (SHOEMAKER, 2006, p. 5).

In communication theory, headlines are traditionally defined as quick routes to contents of newspapers. In doing so, they generally seek to perform two basic functions: (a) to summarize content, and (b) to attract attention to the full newspaper article (SAXENA, 2006). Nonetheless, Althaus et al. (2001), in a research on political news reports, have shown that the function to summarize is not fully achieved because headlines represent a "loose, inadequate or misleading substitute for full-text news-reports in a number of ways" (ALTHAUS et al., 2001, p. 7). They also direct the reader's attention to a single aspect of the story, resulting in the misrepresentation of its content. At the same time, they commonly oversimplify the content of the full text, and conceal relevant information, while often highlighting second-other issues.

Taken that headlines may lack informative potential, their function to attract attention is a more prominent feature to investigate. In a recent paper about sensationalism in news-headlines, MolekKozakowska (2013) describes sensationalism as a discourse strategy for 
V. $11(2)$

$1-22$

maio-ago

2021

"packaging information in news headlines in such a way that news items are presented as more interesting and relevant than might be the case" (MOLEK-KOZAKOWSKA, 2013). The author also acknowledges that two major types of sensationalism can be identified in news outlets: (1) a sensationalist choice of topics to be covered (e.g. corruption, crime, sex), and a (2) a sensationalizing form of information packing, employed to make news appear more relevant or interesting than they really are.

Sensationalism is thus a discursive strategy deliberately applied to news to make it appear newsworthy and/or extraordinary, even when that is not the case. Although those two types of sensationalism are intertwined, the primary focus of this research is on the linguistic strategies employed to promote sensationalism of type 2 in Brazilian news-headlines in the year of 2018. In order to do that, 2.325 front pages from major Brazilian newspapers were weekly collected from The Freedom Forum Institute. Further in this paper, a more detailed account of the methodology of data collection will be provided to the reader. For Dor (2003), all headlines somehow pursue their goal of relevance optimizers, although they may do that in different forms.

In a study on click-baits in news-headlines, Scacco and Muddiman (2016) identified three major types of headlines:

(a) Traditional news-headlines: usually short and clear, they provide an overview of the main idea in an inverted pyramid - structure news story: Brexit Vote Reflects How Diversity Adds to E.U. Pain.

(b) Forward-reference headlines: tend to create more uncertainty about information in a story when compared to traditional headlines. They also function as click-baits and emphasize unknown information: How Far-Right Groups Are Using Orlando to Turn LGBT People Against Muslims and Immigrants.

(c) Question-based headlines: they are designed to create uncertainty by posing a question about information contained in a news story: How 'Kooky' is Trump's Keystone Pipeline Proposal?

As one can see in the examples from study of Scacco and Muddiman (2016), newsworthiness is constructed by stressing or 
foregrounding certain aspects of the story. Along with those lines, Bednarek and Caple (2012) identified several strategies to strengthen newsworthiness and to call the reader's attention, for example: the use of evaluative language; intensification and quantification; comparison, metaphor or simile; references to emotion; negative vocabulary; story structure; references to time and place, nations and communities, individuals; inclusive 'we' and role labels and quotes from 'ordinary' citizens (BEDNAREK; CAPLE, 2012, p. 44).

Moreover, headlines typically contain semantically underdetermined information, ambiguity and vagueness, while they also highly rely on presuppositions and on shared knowledge (IFANTIDOU, 2009). Ambiguity and unspecific information are typically employed in headlines. because, in order to maximize the relevance of a message, speakers/writers may sometimes choose not to be maximally clear. In other words, speakers/writers may purposefully opt to be ambiguous in order to prompt multiple interpretations in the audience (YUS, 2011; AL-JARRAH; ABU-DALU; OBIEDAT, 2018). Example (2) illustrates the syntactic ambiguity of the word "link", which can be a verb and/or a noun. Moreover, the two complex noun phrases ("race hate link", "dog attack murder trial") increase the processing effort on the reader's part:

(2) Race hate link alleged in dog attack murder trial The Guardian, 21/02/2006

(IFANTIDOU, 2009, p. 20.)

Ambiguity is also present in (3), in which the lexical item 'awash' leads to two plausible interpretations: "covered with water" or "containing a large amount of water". The example also involves a metaphorical interpretation of the term. According to RT, metaphorical language is inherent to linguistic communication, and it typically emerges from an attempt to impart complex ideas. From this view, metaphors (and figurative language in general) are seen as cases "at the end of a continuum that includes literal, loose and hyperbolic interpretations" (SPERBER \& WILSON, 2008: 84). Figurative language is thus a variable of several other cognitive operations (e.g. processing sensory and physical inputs, together with semantic knowledge and background knowledge) that may prompt a number of contextual adjustments, allowing for interlocutors to potentially retrieve relevant information drawing from the utterances communicated to them. 
V. $11(2)$

$1-22$

maio-ago

2021
(3) New Orleans is awash in mental health problems Herald Tribune, 22/06/2006 (IFANTIDOU, 2009, p. 21.)

Presuppositions also play a major pragmatic role in headlines, for example, in (4), in which the knowledge of past opium cultivation in Afghanistan, as well as prior expectations of vetoing it, are presupposed:

(4) Flourishing again, Afghanistan's deadly - and lucrative crop

The Guardian, 21/02/2002

(IFANTIDOU, 2009, p. 22.)

In example (5), the presupposition of an existing belief that animals cannot be happy holds:

(5) Animals can be happy too

The Guardian, 29/05/2006

(IFANTIDOU, 2009, p.23.)

As one could see in the examples (2) to (5) from Ifantidou (2009), clarity, brevity, vagueness and curiosity are conflicting forces in the construction of news-headlines. For that reason, it is argued that editorial decisions as to whether information is to be explicated or not encompass a number of related issues (IFANTIDOU, 2009). As a result, readers are commonly required to employ a highly inferential process in order to retrieve the full propositional content of headlines. Headlines are thus considered semantically underdetermined, regardless of topic, style, or news-outlet (IFANTIDOU, 2009). As a consequence, the most common type of cognitive effect in processing the meaning of headlines comes from contextual implication, formed by an "unspecified and fragmented context", as well as by their respective front pages (IFANTIDOU, 2009, p. 5).

To infer meaning, readers of headlines create ad hoc contexts and produce occasion-specific senses (or ad hoc concepts) to form a plausible interpretation of headlines. The resulting interpretation is a function of the interaction among encoded meanings, background assumptions and/ or shared knowledge. In that way, readers are able to make a plausible and relevant interpretations of headlines, although it may not coincide with the content of the news-report or article (IFANTIDOU, 2009). 
For Dor (2003), headlines can optimize relevance when they demand a minimal amount of processing effort: "by being short, clear, unambiguous, and easy to read". In his study of headlines from Israeli news, Dor (2003) concludes that a "good" headline should: "help the reader deduce the maximal amount of contextual effects for the minimal amount of processing" (DOR, 2003, p. 715). The findings of that study, however, as we will point further in this text, show that ambiguity may play an important role in writing headlines. We make a case that it happens because strategic ambiguity fosters multiple interpretations, and tends to act as a clickbait, making the news more attractive than it would otherwise be the case (YUS, 2011).

Taking the framework of newsworthiness and relevance theory into account, in the next section we will describe the methodology of data gathering and analysis of this study.

\section{Methodology}

As previously reported, the central aim of this study is to investigate if/how the framework of Relevance Theory can be associated to the concepts of newsworthiness and/or sensationalism in the headlines on focus.

The headlines analyzed in this study were extracted from the Corpus de Manchetes Brasileiras (CMB - Brazilian News headline Corpus). Containing approximately 2.325 front pages from 56 major Brazilian newspapers, CMB is part of a larger project, developed at a Federal University, aiming at enriching media education initiatives and critical literacy research. In order to compile $\mathrm{CMB}$, frontpages were extracted from the Freedom Forum Institute - Newseum on a weekly basis. The institute is an "interactive museum that promotes free expression while tracing the evolution of communication" (In: http:// www.newseum.org/).

Particularly with respect to the data collected for the present study, the following major steps were taken:

1. Extraction of a sample of front pages from $\mathrm{CMB}$, containing 56 frontpages, one front page per newspaper pertaining to CMB, of the year 2018.

2. Identification of the main headlines in those front pages, together with the main topics they referred to. 
V. 11 (2)

$1-22$

maio-ago

2021

3. Manual analysis of the sample, amounting to 56 headlines (one headline per newspaper).

Throughout the sample analysis, the frontpages selected were stored in a JPG file, as to guarantee that their original format was kept, including their accompanying pictures and typographical features. As for the classification of the sample of headlines in topics, it resulted in the identification of 3 main themes, which were considered more recurrent in the front pages picked for analysis. The topics were: "corruption scandals", "presidential elections" and "the trucker's drivers strike".

In the following section, prior to the qualitative analysis per se, we present a graph of the topics that made the headlines in Brazil in 2018, according to the sample analyzed in this study.

\section{Data Analysis}

The year of 2018 was marked by major events in Brazil: corruption scandals, including the imprisonment of a popular former President, the trucker's strike and Presidential Elections, among others. Graph 1 shows 3 major topics identified as more recurrent in the headlines of 2018 analyzed here.

Graph 1 - Major topics selected for analysis in Brazilian news headlines in 2018

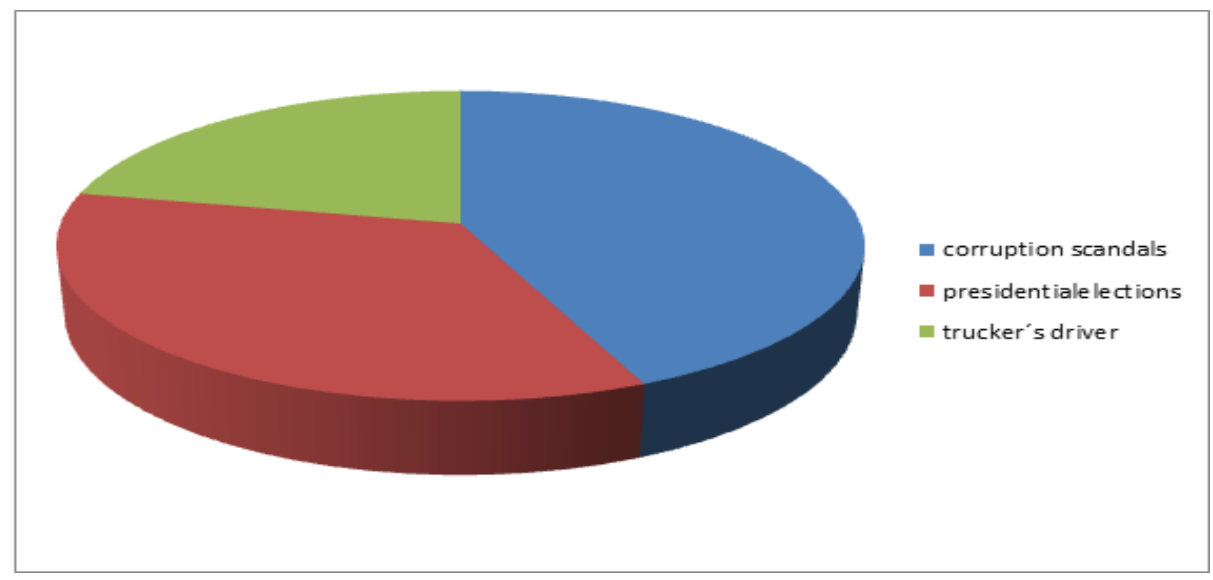

Source: Authors.

Following Graph 1, we will now present a sample analysis of the news headlines, concerning 3 topics identified as recurrent in Brazilian newspapers in 2018. The analysis will be carried out under the light of RT. While we do that, we also make an attempt to associate RT to the notion of newsworthiness and sensationalism. 
The headline in Figure 1 Acordo não dá em nada e Temer entrega a Deus (roughly translated as Deal comes to nothing and Temer surrenders to God) concerned a work stoppage by the country's truckers, held in in May 2018.

Figure 1 - Deal comes to nothing

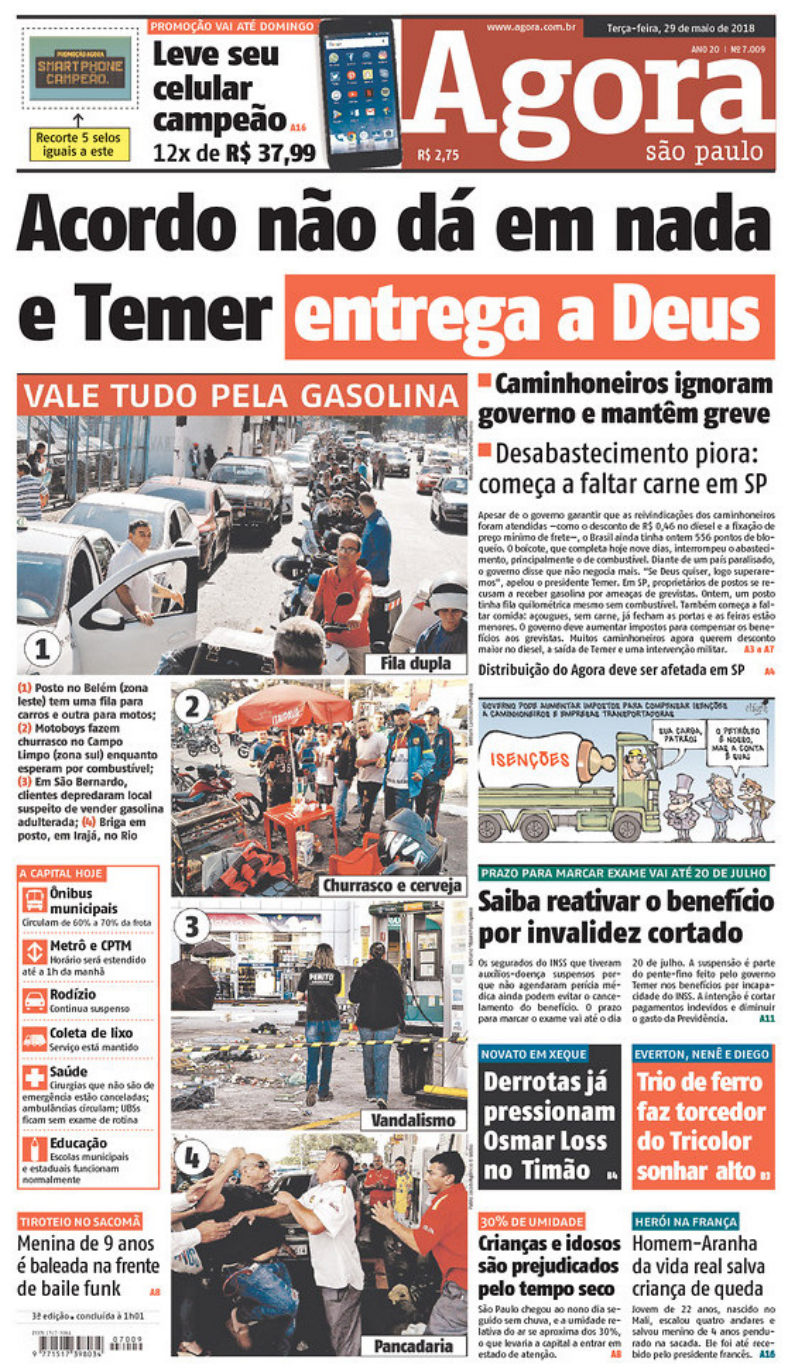

Source: Agora São Paulo.

In the period, truckers called out on the high price of diesel fuel, blocked lanes and prevented any type of cargo vehicle from making it through. Gas and living stocks went undelivered. Two widely used idioms in Brazilian Portuguese were employed in the headline Não dá em nada (equivalent to It comes to nothing) and Entregar a Deus (equivalent to Surrender to God's Will). To catch the reader's attention, the headline employed figurative language, while it also resorts to colloquial language that was easy to process. In the example, the two idioms alluded to an unsuccessful deal between the government and the truckers. In addition, 
V. 11 (2)

1-22

maio-ago

2021

the construction Deals comes to nothing explicated the intended agreement, in which the term deal is profiled as the subject of the sentence. As a result, the headline reinforced the magnitude of the standoff affecting the whole population, and leading to alleged chaos.

It is also noteworthy to mention that the headline in Figure 1 also comprises two acts, linked by the connector AND. In order for readers to be able to infer the meanings involved in the headline, they needed to consider how act 1 constrained the contextual effects derived from the processing effort involved in the interpretation of act 2. Along these lines, from the act Deal [between government and truckers] comes to nothing it was possible to derive assumptions such as: the strike may continue indefinitely, a new deal must be done, the government has lost the bargain, and / or the government was not willing to meet the truckers demands. Those and other assumptions, derived from act 1 , added to the immediate cognitive environment of the readers, who may use them to interpret act 2: Temer surrenders to God's will.

From this view, in case act 2 was constructed in a more direct fashion, such as Fear of failure affecting the deal, the contextual effects resulting from its interpretation would have resulted in the elimination of contradictory assumptions, as well as in the strengthening/weakening of assumptions derived from the first act. In this view, the interpretation of act 2 would then reinforce the assumptions that the strike would continue indefinitely, that the government lost the bargain, and/or that government would not meet the truckers demands. At the same time, that interpretation would eliminate the assumption that a new agreement could be tried soon, by giving rise to the opposing idea that Temer gave up negotiating. In that sense, a more direct headline such as Temer gives up the deal could have become useful in producing various contextual effects (SPERBER; WILSON, 1995, SILVEIRA; FELTES, 1999).

Nonetheless, the author of the headline picked an indirect format that demanded a certain degree of processing efforts from the reader (Temer Surrenders to God). While the construction of this act in its indirect form prompted more contextual effects, it also yielded several different contextual implications: the government / president became fragile with the strike, only an external intervention in the government could solve the standoff, the population could not rely on the government. In sum, the second act, which was produced in an indirect way, made room for different kinds of spin-offs that could potentially become more detrimental to the government than if a more direct form had been selected. 
As for the non-verbal elements related to the headline, they contributed to all inferential processes, in that they pictured a huge line of cars awaiting for gas, followed by the subtitle Vale tudo pela gasolina (All for gas). Together, these features prompted the contextual effect needed for the reader to process the meanings imparted in the news item.

In figure 2, the headline Pará está à beira de um colapso com a greve (roughly translated as Pará - a state in Brazil- is on the verge of collapsing with the strike) alluded to the diesel strike and also made use of a metonym, as well as of hyperbolic language, to catch the reader's eyes. This analysis is also supported by Bednarek and Caple (2012), who described intensification, metonymy and negative vocabulary as strategies to strengthen newsworthiness and sensationalism. Furthermore, the headline constructed newsworthiness by foregrounding the negative aspects of the story (SCACCO; MUDDIMAN 2016), in this case, the trucks stoppage and the chaos it created. Additionally, as Ifantidou (2009) pointed out, brevity, vagueness and curiosity are important features in the construction of news-headlines. In the example, the headline employed unspecified language and fragmented information, for example, about the kind of collapse reported. Those features prompted the readers to form implicated conclusions that potentially attracted their eyes to the news story.

The front page also displayed a photo of numerous stopped trucks, which helped optimize the relevance of the headline. In the case, the association with verbal and non-verbal language was linear and demanded low processing effort. Furthermore, the headlines in figures 1 and 2 triggered a maximal amount of contextual effects by presenting themselves as "interesting and new" (DOR, 2003, p. 715) to the reader. In those examples, the contextual effects intertwined background knowledge, knowledge about the topic, and multiple processes of inference. Those effects also merged with the images that accompanied the headlines, helping the reader form conclusions, and to combine old and new information made relevant for him. 
V. 11 (2) 1-22 maio-ago 2021
Figure 2 - Pará on the verge of collapsing

\section{AMAZONNA}

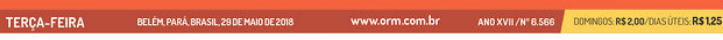
II PARALISAÇÃo dE CAMINHONEIROS COLAPSO COM A GREVE
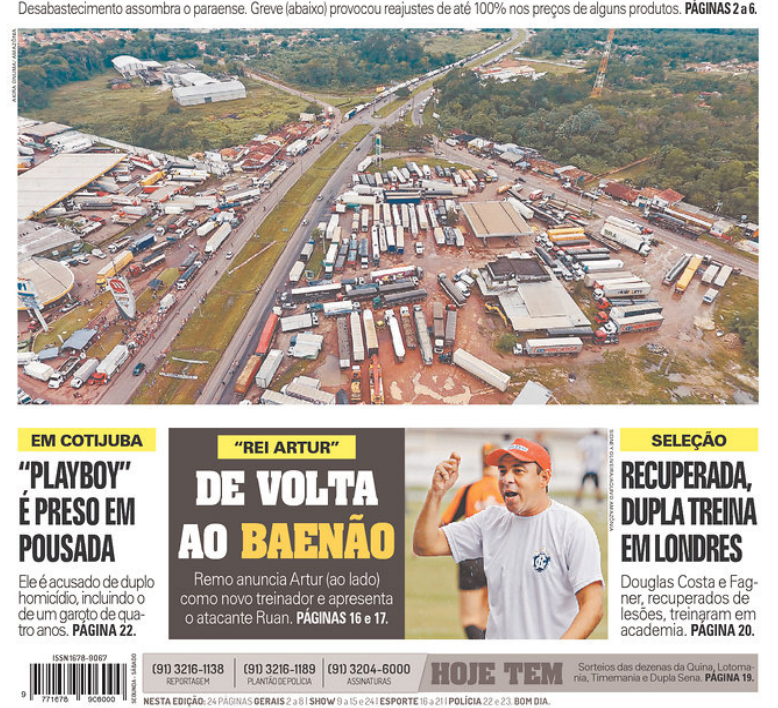

Source: Amazônia.

The headline in Figure 3 Decisão de STF sobre Lula pode ser "passo para trás" (Supreme Court ruling on Lula may be a "step backwards") alluded to one of the most controversial issues in Brazilian Press in the year 2018. 
Figure 3 - Step backwards

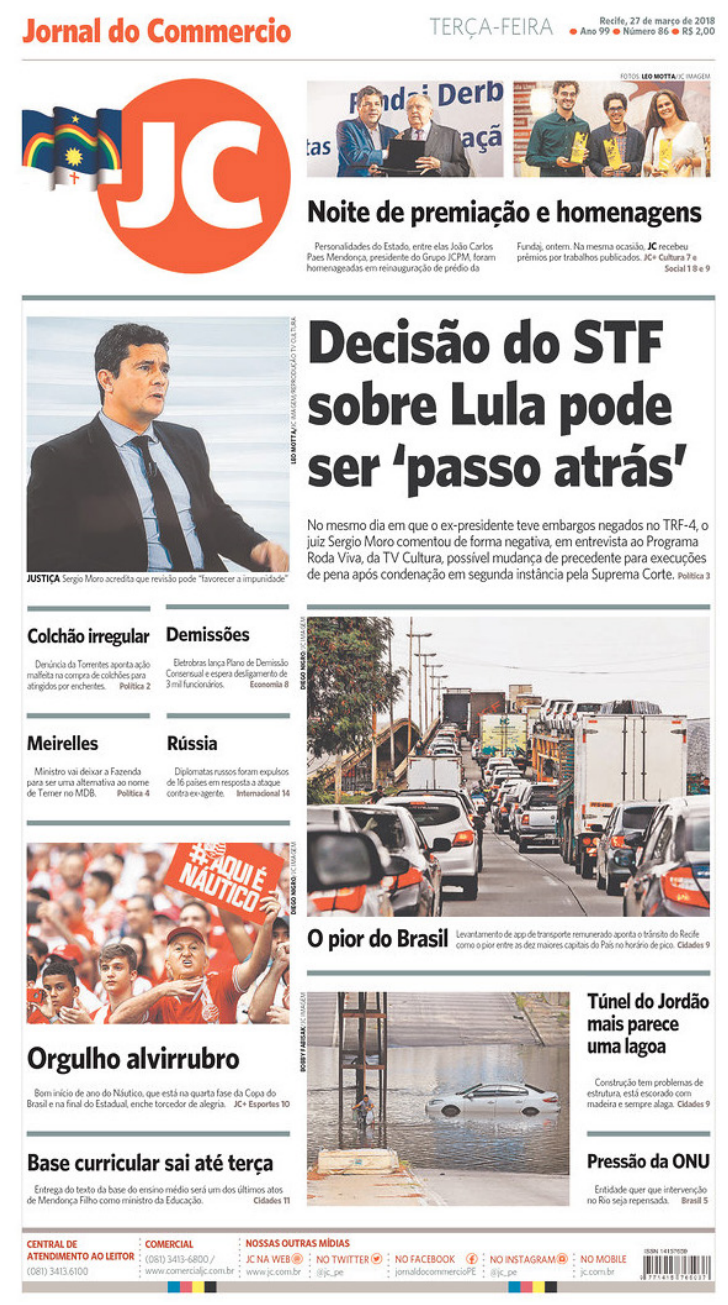

Source: Jornal do Commercio.

The headline employed indirect language that demanded more processing effort from the readers, while it also yielded several different contextual implications (SPERBER; WILSON, 1995, SILVEIRA; FELTES, 1999). Related to the conviction of former President Luiz Inácio Lula da Silva on corruption charges, the headline guided the reader through the process of inference and meaning making by creating ad hoc contexts. At the same time, it produced occasion-specific senses that helped form a plausible interpretation of the story (IFANTIDOU, 2009). Those contextual effects were also related to negativity and were likewise considered detrimental to the decision made by the Supreme Court, which was generally assessed as a step backwards. The headline also compelled the reader to go through the full article in order to find out which step backwards was actually referred to, once it conveyed an unspecified use of the term. The use of quotation marks was also noteworthy in this headline. They suggested forward-referencing, 
V. $11(2)$

$1-22$

maio-ago

2021

while attracting the reader's attention to the news report, and thus functioning as a click-bait (SACCO; MUDDIMAN, 2016).

Alongside the headline, a picture of the Judge Sérgio Moro, who led a sprawling corruption investigation, known as Operation Car Wash, was in focus. The Judge sentenced Lula to nine-and-a-half years in prison for allegedly accepting bribes from contractors in exchange for political favors. Once some legal advisers from varied political stripes argued that the indictment and Moro's ruling were flawed, the quotation enticed the reader to believe that the news story was connected to the judge's reaction to a decision made by the Supreme Court on the case. From this view, the combination of linguistic knowledge and knowledge of the world conflated in the headline to attract the reader's eyes to the news item. That combination also contributed to processing the information at a low cost as attested by Sperber and Wilson (1995) and Silveira and Feltes (1999).

In figure 4, the headline Suprema folga (Supreme break) referred to the Brazilian Supreme Court (STF). It manifested a sarcastic use of the term suprema (supreme), associated with the 5-day-recess the Court is typically occurring during the Holy Week. 
Figure 4 - Supreme break

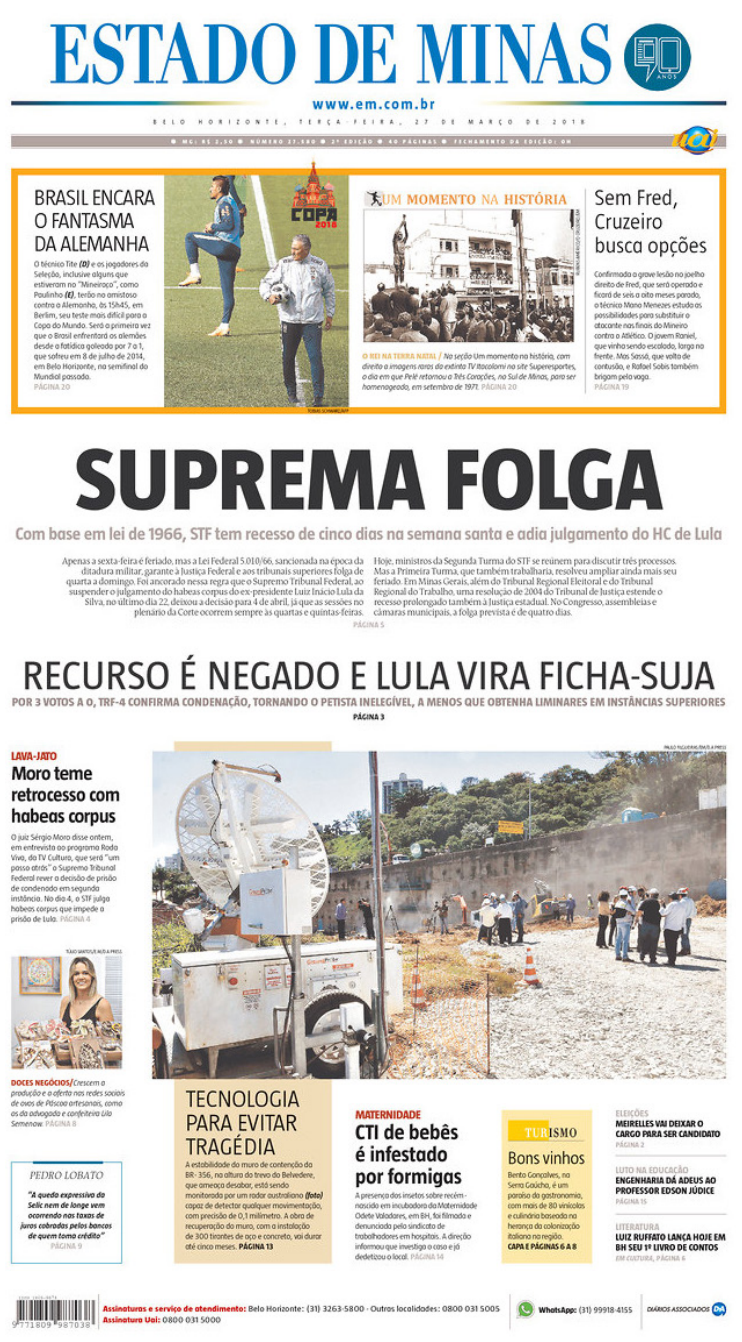

Source: Estado de Minas.

Taken that most Brazilian workers are not given the same benefit, the term evoked the reader's belief that the Supreme Court judges were endowed with unjustified privileges and, more importantly, that the piece of information communicated was novel. In sum, the headline portrayed the respite as an ostensive form of privilege, unattainable for the majority of the population. At the same time, it also played down the court's significance as a trustworthy instance of the Brazilian judiciary system.

As the sample analysis in this paper has shown, the headlines in Brazil in the year of 2018 revolved around three fundamental issues: corruption scandals, presidential elections and social problems in the broader sense, for example, those related to the diesel strike. Along these lines, the news headlines attempted to transform readers into mediated witnesses to these events. As Molek-Kozakowska (2013) 
V. 11 (2)

1-22

maio-ago

2021 suggested, this strategy was more intensively performed when the events were masked to appear more interesting and relevant than they really were. This strategy was illustrated, for example, by Suprema folga (Supreme break), in which there was no real novelty in the information in focus in the news story.

Given that the headlines shown here aimed at bringing the news before the reader's eyes, alleged newsworthy stories typically took a front seat to news items. As a result, "shocking" events, for example, were usually profiled as metonymic subjects of the verbs in focus in the news headlines. This was the case of Acordo não dá em nada (Deal comes to nothing) and Pará está à beira de um colapso com a greve (Pará is on the verge of collapsing with the strike), in which the terms deal (acordo) and Pará (a state in Brazil) were metonymically placed in the subject position.

Following this sample analysis, in the next section, we will make the final remarks concerning this study.

\section{Final remarks}

The headlines analyzed in this study packed information in such a way that the news items appeared more significant and novel than it was many times the case. To achieve that goal, the headlines often employed figurative and/or unspecific language, intended to strengthen the bonds with the readers, while attracting their eyes to the news stories. That strategy may be identified, for example, in the use of set phrases like Não dá em nada, Vale tudo e Entrega para Deus (It comes to nothing, All for something and Temer surrenders to God's will, respectively), which are entrenched in the repertoire of speakers of Brazilian Portuguese, and hence were used as click-baits (SACCO; MUDDIMAN 2016, IFANTIDOU, 2009).

Moreover, with respect to the headlines that demanded a greater degree of processing effort from the audience (SPERBER; WILSON, 1995, SILVEIRA; FELTES, 1999), they also prompted different kinds of spin-offs that potentially conflated with common beliefs, and with previous ideas about the topics in focus, for instance, in Decisão de STF sobre Lula pode ser "passo para trás" (Supreme Court ruling on Lula may be a "step backwards"). In this example, in order to signal its relevance, this headline stressed the common perception that the judiciary system in Brazil lacks effectiveness. 
In sum, our data also pointed to the fact that the headlines analyzed in this study were associated with newsworthiness and sensationalism even when the news were not exactly "novel" (SHOEMAKER, 2006). Evidence to support this argument also draws from the emphasis given to negativity. In this study, out of the 3 major topics identified in the headlines, 2 of them were connected to negativity: corruption scandals and the national 2018 trucker's strike. That said, negativity was commonly foregrounded in the headlines in order to immediately bring the news before the reader's eyes, creating an effect of sensationalism and newsworthiness (SCACCO; MUDDIMAN, 2016).

Last but not least, the findings of this research may be expanded to different kinds of news outlets and topics in order to assure that the more robust data can be cross analyzed. That would be particularly significant if it included, for example, social media and online news platforms.

\section{References}

AL-JARRAH, R. S.; ABU-DALU, A. M; OBIEDAT, H. Translation of strategic ambiguity: A relevance-theoretic analysis. Poznan Studies in Contemporary Linguistics, Berlin, v. 54, n. 1, p. 1-35, 2018).

ALTHAUS, S. L.; EDY, J. A.; PHALEN, P. F. Using substitutes for full-text news stories in content analysis: Which text is best? American Journal of Political Science, Lansing, v. 45, n. 3, p. 707-723, 2001.

BEDNAREK, M.; CAPLE, H. News discourse. London: A\&C Black, 2012.

CARSTON, R. Relevance theory and the saying/implicating distinction. In: HORN, L.; WARD, G. Handbook of Pragmatics. Oxford: Blackwell, 2002, p. 633-656.

DOR, D. On newspaper headlines as relevance optimizers. Journal of Pragmatics, New York, v. 35, n. 5, p. 695-721, 2003.

GRICE, H. P. Logic and conversation. In: COLE, P.; MORGAN, J. L. Sintax and semantics: speech acts. New York: Academic Press, 1975, p. 41-58.

IFANTIDOU, E. Newspaper headlines and relevance: Ad hoc concepts in ad hoc contexts. Journal of Pragmatics, New York, v. 41, n. 4, p. 699-720, 2009.

MOLEK-KOZAKOWSKA, K. Towards a pragma-linguistic framework for the study of sensationalism in news headlines. Discourse \& Communication, Thousand Oaks, v. 7, n. 2, p. 173-197, 2013.

MONTGOMERY, M. The discourse of broadcast news: a linguistic approach. Abingdon: Routledge, 2007. 
V. $11(2)$

$1-22$ maio-ago 2021

SCACCO, J. M.; MUDDIMAN, A. Investigating the influence of "clickbait" news headlines. Engaging News Project Report, 2016.

SAXENA, S. Headline Writing. London: Sage Publications, 2006.

SHOEMAKER, P. J. News and newsworthiness: a commentary. Communications, Berlin, v. 31, n. 1, p. 105-111, 2006.

SILVEIRA, J. R. C.; FELTES, H. P. M. Pragmática e cognição: a textualidade pela relevância. Porto Alegre: EDIPUCRS, 1999.

SPERBER, D.; WILSON, D. Relevance: communication and cognition. Oxford, Cambridge: Blackwell, 1995.

SPERBER, D.; WILSON, D. A deflationary account of metaphors. In: GIBBS, JR, R. W. (org.) The Cambridge handbook of metaphor and thought. Cambridge: Cambridge University Press, 2008, p. 84-105.

WILSON, D; CARSTON, R. A unitary approach to lexical pragmatics: relevance, inference and ad hoc concepts. In: BURTON-ROBERTS, N. Pragmatics. Basingstoke: Palgrave-Macmillan, 2007, p.230-259.

WILSON, D.; SPERBER, D. Teoria da Relevância. Linguagem em (Dis)curso, Tubarão, v. 5, p. 221-261, 2005.

YUS, F. Cyberpragmatics: Internet-mediated communication in context. John Benjamins Publishing Company, 2011. 